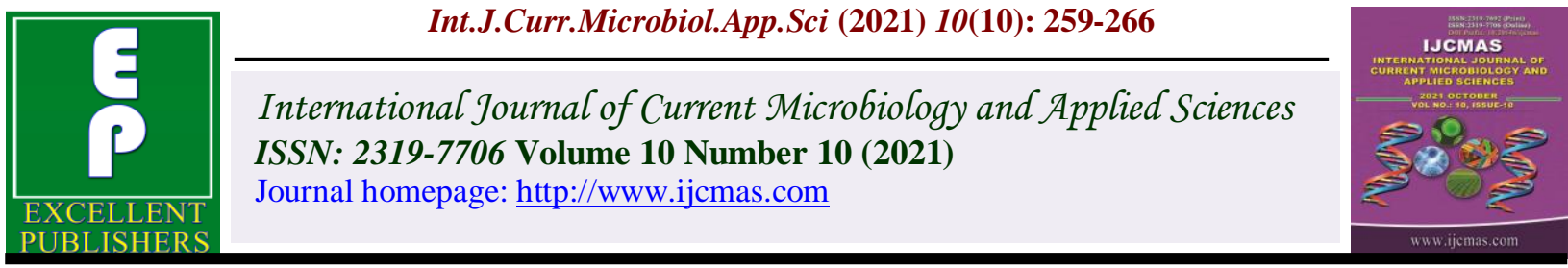

\title{
Studies on the Effect of Different Plant Densities and Levels of CRF on Growth, Yield and Quality of Flowers of Statice (Limonium sinuatum L.)
}

\author{
Nishchay Galage*, Samir Ebson Topno and Vipin M. Prasad
}

\author{
Department of Horticulture (Floriculture and Landscaping), Department of Horticulture, \\ Sam Higginbottom University of Agriculture, Technology and Sciences, \\ Prayagraj, U.P - 211007, India \\ *Corresponding author
}

\section{A B S T R A C T}

\section{Keywords}

Controlled-release Fertilizers (CRF), Limonium, Spacing

Article Info

Accepted:

10 September 2021 Available Online: 10 October 2021
A Field Experiment was conducted during Rabi season 2019-2020 at Experimental field, Department of Horticulture, Naini Agriculture Institute, Sam Higginbottom University of Agriculture, Technology and Sciences, Prayagraj (U.P.), India. The experiment was Evaluated in a Factorial randomized block design (FRBD) with three replications and 12 treatments. Among the CRF of $6 \mathrm{~g}$ recorded significantly higher growth parameters followed by CRF of $4 \mathrm{~g}, 2 \mathrm{~g}$ and control. Spacing of $45 \mathrm{~cm} \times 60 \mathrm{~cm}$ had a considerable influence on the number of leaves and length of leaves. Whereas, plant height was significantly higher with a spacing of $15 \mathrm{~cm} \times 30 \mathrm{~cm}$ at all the growth stages. In flowering parameters, Controlled-release Fertilizers and spacing had a significance influence on the flowering parameters of statice. CRF of $6 \mathrm{~g}$ per plant obtained notably higher flowering parameters like length of flower stalk and day of flower bud initiation to the day of harvesting whereas, highest delay in flower stalk initiation was observed in Control. The closer spacing of $15 \mathrm{~cm} \times 30 \mathrm{~cm}$ had considerable influence on days required to flower stalk initiation/appearance, length of flower stalk and day of flower bud initiation to the day of harvesting or flowering duration. The higher yield with superior quality of flowers obtained with CRF of $6 \mathrm{~g}$ with wider spacing of $45 \mathrm{~cm} \times 60 \mathrm{~cm}$.

\section{Introduction}

Limonium (Limonium sinuatum L.) is the modern name for 'Statice' or sometimes 'Sea Lavender'. The symbol of permanence and consistency is the meaning of the flower called Limonium sinuatum. It adds variety in terms of color, flower size and shape to the beautiful world of flowers. The production of Limonium is of special interest because the flowers may be used either fresh or dried and are available in an assortment of colors. The plants are grown in the mixed borders, rock gardens, meadows, cutting gardens, good for dried flower arrangements and cut flowers in gardens as well as greenhouses. They are used 
as filler in baskets and other flower arrangements. The more dainty panicled kinds are as useful as gypsophila in mixed bouquets. The flowers may be dried and used as everlasting ones. Some of the species are also used for medicinal purposes.

These plants once belonged to the genus Armeria and were later changed to the genus Limonium and It belongs to family Plumbaginaceae. The name 'Statice' was entirely rejected botanically but is still in common usage. Genus Limonium is classified into annual and perennial ones. The important annual species are $L$. sinualum and $L$. saworowii. Important annual varieties are Midnight Blue, Twilight, Lavender, Blue Bonnet, Iceberg, Gold Coast, Velvet Wings and Crystal Yellow. Perennial ones include several species namely $L$. dumosum, $L$. altaica, L. perezii, L. latifolium, L. caspia and Limonium hybrids. The Japanese and the Dutch Limonium seedlings develop as rosette plants. Leaves are radical and tufted or alternate along the stem in shrubby forms. Average daily temperature between 22 and $27^{\circ} \mathrm{C}$ and night temperatures between 12 and $16^{\circ} \mathrm{C}$ are the most suitable temperatures for ideal flower production. For winter production, a minimum temperature of $15^{\circ} \mathrm{C}$ is required although a slightly higher temperature is preferred.

The flowers in many species are produced in loose panicles and others, are born in branching spikes. Its branched, hairy stems typically grow to $30-46 \mathrm{~cm}$ in height and are topped with clusters of tiny, papery florets. Its blossoms feature white corollas and calyxes available in lavender, white, pink, yellow or purple tones - the latter of which are known to retain their color very well. The panicle is a compound raceme and comprising of numerous sub-spikes containing numerous pairs of flower buds. This characteristic makes Limonium a popular filler flower, working exceptionally well in fresh and dry arrangements. Aside from their unique texture, Limonium blossoms are also recognized for their musky scent; some say it's not very appealing, but this quality doesn't detract from the plant's overall beauty! To lessen the scent's blow, arrangements with Limonium should be placed in cool, well-ventilated areas. Harvesting can be expected three to four months after planting (free flowering varieties), depending upon the varieties. Flowers should be picked when about 90 percent of flowers show color and are open.

\section{Materials and Methods}

The present research was carried out on the Experimental field. Department of Horticulture, Sam Higginbottom University of Agriculture Technology and Science, Prayagraj (U.P), During Rabi season 20192020. The experiment was laid out in a Factorial randomized block design (FRBD) with three replications and 12 treatments. The First factor consisted of three Different levels of CRF (grams) i.e., $2 \mathrm{~g}\left(\mathrm{C}_{1}\right), 4 \mathrm{~g}\left(\mathrm{C}_{2}\right), 6 \mathrm{~g}\left(\mathrm{C}_{3}\right)$ and $0 \mathrm{~g} \quad\left(\mathrm{C}_{4}\right)$. Second factor involved different spacing densities $15 \mathrm{~cm} \times 30 \mathrm{~cm}\left(\mathrm{~S}_{1}\right), 30 \mathrm{~cm} \times$ $45 \mathrm{~cm}\left(S_{2}\right)$ and $45 \mathrm{~cm} \times 60 \mathrm{~cm}\left(S_{3}\right)$.Beds were prepared and plants were planted with respective spacing and a fixed basal dose of different levels of CRF applied. The standard cultural practices were followed and three to four plants were randomly tagged in each plot for recording growth and flower yield parameters.

Observations were recorded at 60, 90 and 120 days after sowing (DAS) on different vegetative growth parameters like Plant height, Number of leaves, and Length of leaves, Photosynthetic characteristics like Leaf area, Leaf weight and Chlorophyll content. Flowering parameters like Number of days required to flower stalk initiation/ appearance, Length of the flower stalk, Day of flower bud 
initiation to the day of harvesting. (Flowering Duration), Yield parameters like Number of flower stalks per plant, Number of flower spikes per plant, Number of flower stalks per plot and Postharvest parameters like Vase life of flower when placed in water and $2 \%$ sucrose solution were recorded and data were pooled. The data analysed at 5\% level of significance using WINDOWSTAT 9.3 version.

\section{Climatic condition in the experimental site}

The area of Prayagraj District comes under a subtropical belt in southeastern Uttar Pradesh. The climate of this region is a humid subtropical climate. The annual mean temperature is $26.1^{\circ} \mathrm{C}$ and the monthly mean temperature is $18-29^{\circ} \mathrm{C}$.

\section{Results and Discussion}

The results of the Experiment are summarized below:-

\section{Growth Parameters}

The plant height of a crop is a direct index to measure growth and vigor. In general, plant height increases gradually with the advancement of age. Concerning the CRF effect, higher plant height was observed in a higher level of CRF (6g) whereas, lesser plant height was observed in Control. As CRF, which provides a gradual nutrient supply for a long period of time improves $\mathrm{N}$ fertilizer use efficiency and reduces $\mathrm{N}$ leaching losses. In this study statice seeds responded well even to low rates of fertilization. Hence Growth of the plant due to controlled release fertilizes has also been reported by Asrar et al., (2014) in potted chrysanthemum and by Carpio et al., (2005) in Ipomoea carneasp fistulosa. A decreasing trend was observed in plant height from 60 DAS to 120 DAS till harvest. Maximum plant height was recorded at $15 \mathrm{~cm}$ $\times 30 \mathrm{~cm}$ and the minimum was recorded at $45 \mathrm{~cm} \times 60 \mathrm{~cm}$. Concerning the CRF effect, number of leaves is more under the higher level of CRF of $6 \mathrm{~g}$ followed by $4 \mathrm{~g}, 2 \mathrm{~g}$ and control. Whereas a lesser number of leaves were found in control. The use of controlledrelease fertilizers (CRF) Osmocote was expected to enhance the efficiency of nutrient utilization. An increasing trend was observed in number of leaves from 60 DAS to 120 DAS till harvest. Here, the widest spacing of $45 \mathrm{~cm}$ $\mathrm{x} 60 \mathrm{~cm}$ resulted more number of leaves, while less number of leaves per plant was recorded in closely spaced plants of $15 \mathrm{~cm} \times 30 \mathrm{~cm}$. Concerning the CRF effect, number of leaves is more under the higher level of CRF of $6 \mathrm{~g}$ followed by $4 \mathrm{~g}, 2 \mathrm{~g}$ and control. Whereas a lesser number of leaves were found in control. In Chrysanthemum, the application of potassium fertilizer led to flowering ahead of time, increased plant height, number of leaves, and larger flowers (Zeb, 2015), which is consistent with our findings. An increasing trend was observed in number of leaves from 60 DAS to 120 DAS till harvest. Here, the widest spacing of $45 \mathrm{~cm} \times 60 \mathrm{~cm}$ resulted more number of leaves, while less number of leaves per plant was recorded in closely spaced plants of $15 \mathrm{~cm} \times 30 \mathrm{~cm}$. The present results conform with the earlier findings of Singh and Singh (2005) in tuberose cv. Double and Vedavathi et al., (2014) in Asiatic lily (Lilium spp.). Concerning the CRF effect, the length of leaves per plant was highest under the higher level of CRF of $6 \mathrm{~g}$ followed by $4 \mathrm{~g}, 2 \mathrm{~g}$ and control. Whereas the lowest length of leaves was found in control. Hence, in accordance with Poole and Sheeley J G (1977) reported that applying $4 \mathrm{~g}$ of Osmocote in a 10 $\mathrm{cm}$ diameter pot resulted in better seedling growth than applying $16 \mathrm{~N}-1.7 \mathrm{P}-10.3 \mathrm{~K}$ water-soluble nutrient fertilizer three times per month using a $200 \mathrm{mg} / \mathrm{L}$ concentration. An increasing trend was observed in the length of leaves from 60 DAS to 120 DAS till harvest. Sodkowski and Rekowska (2003) reported the 
longest leaf from closer spacing. Concerning the CRF effect, leaf weight was recorded highest under the higher level of CRF of $6 \mathrm{~g}$ followed by $4 \mathrm{~g}, 2 \mathrm{~g}$ and control. Whereas the lowest leaf weight was found in control. An increasing trend was observed in leaf weight from 60 DAS to 120 DAS till harvest. Planting at a closer spacing of $15 \mathrm{~cm} \mathrm{x} 30 \mathrm{~cm}$ recorded minimum leaf weight and widest spacing of $45 \mathrm{~cm} \times 60 \mathrm{~cm}$ recorded maximum leaf weight. Because of the increased growth rate, high-density plantings could be harvested earlier than wider spaced plants with a consequential shorter growing season.. A similar trend of results was also reported by Rai (1981). Concerning the CRF effect, Maximum leaf area was observed in a higher level of CRF of $6 \mathrm{~g}$ followed by $4 \mathrm{~g}, 2 \mathrm{~g}$ and control. In this experiment higher level of CRF appears to be more than adequate in evoking a good response from statice plants due to sufficient CRF in this treatment which was the most important plant nutrient that generally influences the leaf growth. Similarly reported that leaf area and chlorophyll content vary according to mineral status $(\mathrm{N}, \mathrm{P}, \mathrm{K})$ of plants (Salisbury and Ross, 1992; Taiz and Zeiger, 1998). Increased leaf area and chlorophyll content of AMF colonized plants (Aguilera-Gomez et al., 1999; Estrada-Luna and Davies, 2003) were related to improved P uptake (Fitter, 1988). Concerning the CRF effect, Maximum chlorophyll content was observed in a higher level of CRF of $6 \mathrm{~g}$ followed by $4 \mathrm{~g}, 2 \mathrm{~g}$ and control. Here, plants fertilized with CRF had greater leaf chlorophyll than control. Similar effects were obtained in a pot experiment of Calla palustris, plant height, growth potential and chlorophyll content in CRF treatments were better than control (Hou et al., 2008).

\section{Flowering parameters}

Concerning the CRF effect, a minimum number of days required to flower stalk initiation was observed in a higher level of CRF of $6 \mathrm{~g}$ followed by $4 \mathrm{~g}, 2 \mathrm{~g}$ and control.

A perusal of the data shows variations in days taken for visible flower bud formation on different levels of CRF treatments were found to be significant. The use of controlled-release fertilizers resulted in the earliest flowering was reported by Gillespie and Thomas (1982) in potted Cyclamen. Concerning the CRF effect, the highest length of flower stalk was observed in a higher level of CRF of $6 \mathrm{~g}$ followed by $4 \mathrm{~g}, 2 \mathrm{~g}$ and control. The same response has been found in Walker and Huntt (2000), testing four types of CRFs with three different application rates, also found that morphological parameters, especially shoot growth response, generally increased with application rate. The present findings are in accordance with those reported by Gowda and Jayanthi (1986) in marigold, Gowda and Jayanthi (1988) in china aster and Bhattacharya (1997) in rose. Concerning the CRF effect, Perusal of the data shows variations in a day of flower bud initiation to the day of harvesting on different levels of CRF treatments were found to be significant. The maximum flowering duration was observed in a higher level of CRF of $6 \mathrm{~g}$ followed by $4 \mathrm{~g}, 2 \mathrm{~g}$ and control. The increase in the duration of flowering in plants receiving the conjoint application of controlled-release fertilizer might ascribe to an increased duration of availability of nutrients to the plants. The same results have also been reported by Sharma (2009) and Dorajeerao et al., (2012) in chrysanthemum. 
Table.1 Effect of plants spacing and different levels of CRF on vegetative traits of statice

\begin{tabular}{|c|c|c|c|c|c|c|c|c|c|}
\hline \multirow[t]{2}{*}{ Treatments } & \multicolumn{3}{|c|}{ Plant height(cm) } & \multicolumn{3}{|c|}{ Number of Leaves } & \multicolumn{3}{|c|}{ Length of Leaves (cm) } \\
\hline & $\begin{array}{c}\text { 60 } \\
\text { DAS }\end{array}$ & $\begin{array}{c}90 \\
\text { DAS }\end{array}$ & $\begin{array}{l}120 \\
\text { DAS }\end{array}$ & $\begin{array}{c}\text { 60 } \\
\text { DAS }\end{array}$ & $\begin{array}{c}90 \\
\text { DAS }\end{array}$ & $\begin{array}{c}120 \\
\text { DAS }\end{array}$ & $\begin{array}{c}\text { 60 } \\
\text { DAS }\end{array}$ & $\begin{array}{c}90 \\
\text { DAS }\end{array}$ & $\begin{array}{l}120 \\
\text { DAS }\end{array}$ \\
\hline \multicolumn{10}{|c|}{ CRF (C) } \\
\hline $\mathbf{C}_{1}$ & 14.34 & 44.97 & 79.74 & 38.30 & 63.22 & 80.04 & 11.34 & 12.52 & 13.74 \\
\hline $\mathrm{C}_{2}$ & 15.09 & 45.85 & 80.70 & 41.00 & 66.96 & 85.67 & 12.59 & 13.78 & 15.11 \\
\hline $\mathrm{C}_{3}$ & 16.21 & 46.55 & 84.55 & 42.74 & 71.52 & 93.56 & 13.78 & 15.26 & 16.74 \\
\hline $\mathrm{C}_{4}$ & 13.47 & 43.42 & 76.22 & 36.81 & 35.89 & 72.59 & 10.22 & 11.18 & 12.59 \\
\hline S.Em \pm & 0.135 & 0.244 & 0.320 & 0.124 & 0.570 & 0.945 & 0.150 & 0.204 & 0.204 \\
\hline $\begin{array}{c}\text { C.D. } \\
(\mathbf{P}=\mathbf{0 . 0 5})\end{array}$ & 0.397 & 0.716 & 0.939 & 0.365 & 1.672 & 2.772 & 0.441 & 0.597 & 0.599 \\
\hline \multicolumn{10}{|c|}{ Spacing (S) } \\
\hline $\mathbf{S}_{1}$ & 15.13 & 45.65 & 81.28 & 38.89 & 58.42 & 80.50 & 11.48 & 12.58 & 14.11 \\
\hline $\mathbf{S}_{2}$ & 14.78 & 45.40 & 80.39 & 39.81 & 59.25 & 82.50 & 12.00 & 13.25 & 14.50 \\
\hline $\mathbf{S}_{\mathbf{3}}$ & 14.43 & 44.56 & 79.25 & 40.45 & 60.53 & 85.89 & 12.47 & 13.72 & 15.03 \\
\hline S.E.m \pm & 0.117 & 0.212 & 0.277 & 0.108 & 0.494 & 0.819 & 0.130 & 0.176 & 0.177 \\
\hline $\begin{array}{c}\text { C.D. } \\
(\mathbf{P}=\mathbf{0 . 0 5})\end{array}$ & 0.344 & 0.620 & 0.813 & 0.316 & 1.448 & 2.401 & 0.382 & 0.517 & 0.519 \\
\hline
\end{tabular}

Table.2 Effect of plants spacing and different levels of CRF on Flowering traits of statice

\begin{tabular}{|c|c|c|c|}
\hline Treatments & $\begin{array}{l}\text { Number of days } \\
\text { required to flower } \\
\text { stalk initiation (Days) }\end{array}$ & $\begin{array}{l}\text { Length of the } \\
\text { flower stalk } \\
\text { (cm) }\end{array}$ & $\begin{array}{c}\text { Flowering } \\
\text { duration(Days) }\end{array}$ \\
\hline \multicolumn{4}{|c|}{ CRF (C) } \\
\hline $\mathrm{C}_{1}$ & 54.30 & 74.30 & 36.92 \\
\hline $\mathrm{C}_{2}$ & 52.07 & 77.37 & 38.37 \\
\hline $\mathbf{C}_{3}$ & 49.63 & 79.93 & 39.37 \\
\hline $\mathrm{C}_{4}$ & 56.26 & 69.18 & 35.92 \\
\hline S.Em \pm & 0.884 & 0.321 & 0.051 \\
\hline C.D. $(P=0.05)$ & 2.593 & 0.941 & 0.152 \\
\hline \multicolumn{4}{|c|}{ Spacing (S) } \\
\hline$S_{1}$ & 53.83 & 76.72 & 38.05 \\
\hline $\mathbf{S}_{2}$ & 53.14 & 75.34 & 37.61 \\
\hline $\mathbf{S}_{\mathbf{3}}$ & 52.22 & 73.53 & 37.27 \\
\hline S.E.m \pm & 0.766 & 0.278 & 0.044 \\
\hline C.D. $(P=0.05)$ & 2.246 & 0.815 & 0.131 \\
\hline
\end{tabular}


Table.3 Effect of plants spacing and different levels of CRF on Yield traits of statice

\begin{tabular}{|c|c|c|c|}
\hline Treatments & $\begin{array}{c}\text { Number of flower } \\
\text { stalks per plant }\end{array}$ & $\begin{array}{c}\text { Number of } \\
\text { flower spikes } \\
\text { per plant }\end{array}$ & $\begin{array}{c}\text { Number of flower } \\
\text { stalks per plot }\end{array}$ \\
\hline \multicolumn{2}{|c|}{ CRF (C) } \\
\hline $\mathbf{C}_{\mathbf{1}}$ & 5.67 & 17.96 & 63.00 \\
\hline $\mathbf{C}_{\mathbf{2}}$ & 6.82 & 22.96 & 67.78 \\
\hline $\mathbf{C}_{\mathbf{3}}$ & 7.70 & 27.18 & 72.67 \\
\hline $\mathbf{C}_{\mathbf{4}}$ & 4.30 & 14.26 & 57.89 \\
\hline S.Em $\mathbf{E}$ & 0.053 & 0.111 & 0.206 \\
\hline C.D. $(\mathbf{P}=\mathbf{0 . 0 5})$ & 0.156 & 0.327 & 0.604 \\
\hline & & & \\
\hline $\mathbf{S}_{\mathbf{1}}$ & 5.78 & 19.00 & 67.25 \\
\hline $\mathbf{S}_{\mathbf{2}}$ & 6.08 & 20.47 & 65.17 \\
\hline $\mathbf{S}_{\mathbf{3}}$ & 6.50 & 22.31 & 63.58 \\
\hline S.E.m \pm & 0.046 & 0.097 & 0.178 \\
\hline C.D. $(\mathbf{P}=\mathbf{0 . 0 5})$ & 0.135 & 0.283 & 0.523 \\
\hline
\end{tabular}

\section{Yield Parameters}

Concerning the CRF effect, data shows that maximum number of flower stalks per plant was observed in higher level of CRF of $6 \mathrm{~g}$ followed by $4 \mathrm{~g}, 2 \mathrm{~g}$ and control.

This may be due to the use of controlledrelease fertilizer, which might explain the vital physiological roles of controlled-release fertilizer in different growth and development processes.

Its supply would activate the meristematic system due to the increase in cell number and size, thereby stimulating vegetative growth and by sequence flowering aspects which was also reported by Asrar et al., (2014) in potted chrysanthemum, Andiru et al., (2013) in Impatiens wallerana, Zhu et al., (2009) in Chrysanthemum morifolium, Kalmotia (2007), Bloome and Dambre (1980) in Gerbera. Concerning the CRF effect, data shows that maximum number of flower spikes per plant was observed in a higher level of CRF of $6 \mathrm{~g}$ followed by $4 \mathrm{~g}, 2 \mathrm{~g}$ and control. This result was found similar to Odenwald and Turner, 2006.Concerning the CRF effect, data shows that maximum number of flower stalks per plot was observed in a higher level of CRF of $6 \mathrm{~g}$ followed by $4 \mathrm{~g}, 2 \mathrm{~g}$ and control. Same result was found similar to Yahya et al., (1999)studied the effects of four rates of controlled-release fertilizer (14N: $14 \mathrm{P}_{2} \mathrm{O}_{5}: 14 \mathrm{~K}_{2} \mathrm{O}, 3-$ month release period @ 5, 10, 15 and $20 \mathrm{~g}$ for every liter of medium) in a coconut coir dust-based growing medium on three cultivars of potted chrysanthemums.

They reported that foliar analysis indicated increased leaf $\mathrm{N}$ and $\mathrm{K}$ contents correspondingly with increasing fertilizer rates. Plants grown at higher fertilizer rates produced more flowers, however, changes in fertilizer rates did not affect the longevity of individual flowers.

From this field investigation, it could be concluded that, The higher yield with superior quality flowers was obtained with CRF of $6 \mathrm{~g}$ and spacing of $45 \mathrm{~cm} \times 60 \mathrm{~cm}$. 


\section{References}

Aguilera-Gomez, L., F. T. Davies, Jr., V. Olalde-Portugal, S. A. Duray, and L. Phavaphutanon. 1999. Influence of phosphorus and endomycorrhiza on gas exchange, plant growth and mycorrhizal development of chile ancho pepper (Capsicum annuum L. cv. San Luis). Photosynthetica 36(3):441-449.

Andiru G, Pasian C C, Frantz J M and Jones M L. 2013. Greenhouse production of Impatienswallerana using a controlledrelease fertiliser produces quality finished plants with enhanced garden performance. Journal of Horticultural Science and Biotechnology 88: 216-222.

Asrar A W, Elhindi K and Salam E M A. 2014. Growth and flowering response of chrysanthemum cultivars to Alar and slow-release fertilizer in an outdoor environment. Journal of Food, Agriculture and Environment 12: 963971.

Bhattacharya Jayeeta 1997. Effect of plant density on growth and yield of hybrid tea rose cv. Gladiator. A M.Sc.(Agri.) thesis submitted to P.K.V, Akola.

Blomme R and Dambre P. 1980.Cultural, substrate and fertilizer trails on gerbera. VerbondsnieuwsVoor belgischesierteult 24: 551-554.

Carpio L A, Davies F T and Arnold M A. 2005. Arbuscular Mycorrhizal Fungi, Organic and inorganic controlled-release fertilizers: Effect on growth and leachate of container-grown bush morning glory (Ipomoea carnea ssp. fistulosa) under high production temperatures. Journal of the American Society for Horticultural Science. 130: 131-139.

Dorajeerao A V D, Mokashi A N, Patil V S, Venugopal C K, Lingaraju S and Koti R V. 2012. Effect of graded levels of nitrogen and phosphorus on growth and yield of garland chrysanthemum
(Chrysanthemum coronarium L.). Karnataka Journal of Agricultural Science 25: 224-228.

Estrada-Luna, A. A. and F. T. Davies, Jr. 2003. Arbuscular mycorrhizal fungi influence water relations, gas exchange, abscisic acid and growth of micropropagated chile ancho pepper (Capsicum annuum L. cv. San Luis) plantlets during acclimatization and post-acclimatization. J. Plant Physiol. 160:1073-1083.

Gillespie J B and Thomas M B. 1982. Influence of nitrogen, phosphorus, potassium and lime growth and flowering of potted cyclamen. Combined Proceedings International plant propagators society 32: 383-389.

Gowda, J. V. N. and Jayantni, R. 1986. Studies on the effect of spacing and season of planting on growth and yield of marigold (Tagetes erecta. Linn). South Ind. Hort., 34 (3): 198-203.

Gowda, J. V. N. 1985. Investigation on horticultural practices in the production of China aster (Callistephus chinensis L. Ness) Ph. D. Thesis, University of Agricultural Sciences, Bangalore (India).

Hou, X. L., M. Zhang, L. L. Duan, H. Wang, and R. L. Song. 2008. Effects of Controlled Release Compound Fertilizers on Leaching Loss of Nutrient and Growth of Calla. Journal of Soil \& Water Conservation 22: 158-162.

Kalmotia P. 2007.Effect of Growth Regulators, Organic and Inorganic Fertilizers on Pot Grown Gerberacv. 'Harley'. M.S.c Thesis. Depatment of Floriculture and Landscape Architecture. Dr. YS Parmar University of Horticulture and Forestry. Solan.123p.

Odenwald, N. G. \& Turner, J. R. 2006. Identification, selection, and use of southern plants for landscape design 4th edClaitor's Publishing Baton Rouge, L A. 
Poole H A, Seeley J G. 1977. Effects of artificial light sources. intensity, watering frequency, and fertilization practices on growth of Cattleya, Cymbidium, and Phalaenopsis orchids. Am Orchid Soc Bull 46:923-928.

Rai, M. M. 1981. Principles of Soil Science. Machillan India Limited, Calcutta. pp. 179-182.

Salisbury F. B. and C. W. Ross. 1992. Plant physiology. 4th ed. Wadswordth, Belmont, Calif.

Sharma K. 2009. Selection and Characterization of Endophytic and Rhizospheric Microorganisms of Chrysanthemum (Dendranthema grandiflora Tzvelve). M.Sc. Thesis submitted to Dr Y S Parmar University of Horticulture and Forestry, Nauni, Solan (HP) 133p.

Singh, S. K. and Singh, R. K. 2005. Combined effect of Nitrogen and spacing on tuberose cv. Double. Progressive Agriculture. 5(1\&2): 70-73.

Sodkowski P, Rekowska E. 2003. The effect of covering and cultivation methods on crisp lettuce yields. Folia Hort., 15(1): 19-23.

Taiz, L. and E. Zeiger. 1998. Plant physiology. 2nd ed. Sinauer, Sunderland, Mass.

Vedavathi $\mathrm{R} \quad \mathrm{S}$, Manjunatha $\mathrm{B}$, Basavanagowda M G, Thipanna K S, Ravishankar M Patil. 2014. Effect of spacing and nitrogen levels on quantity and quality characteristics of Asiatic lily. Hort Flora Research Spectrum. 2014; 3(4):339-343.

Walker, R. F., Huntt, C. D. 2000. Production of containerized Jeffrey pine planting stock for harsh sites: growth and nutrition as influenced by controlledrelease fertilization. West. J. App. For. 15 (2), 86-91.

Yahya A, Safie H and Mokhlas M S. 1999. Growth and flowering responses of potted chrysanthemums in a coir dustbased medium to different rates of controlled-release fertilizer. Journal of Tropical Agriculture and Food Science 27: 39-46.

\section{How to cite this article:}

Nishchay Galage, Samir Ebson Topno and Vipin M. Prasad. 2021. Studies on the Effect of Different Plant Densities and Levels of CRF on Growth, Yield and Quality of Flowers of Statice (Limonium sinuatum L.). Int.J.Curr.Microbiol.App.Sci. 10(10): 259-266. doi: https://doi.org/10.20546/ijcmas.2021.1010.031 